\title{
Penile elephantiasis: a rare consequence of inappropriate use of condom as external urinary collection receptacle
}

\author{
Sagorika Paul, ${ }^{1}$ Deepansh Dalela, ${ }^{1}$ Jai Prakash, ${ }^{1}$ Satyanarayan Sankhwar ${ }^{2}$
}

'Department of Urology, King George Medical University, Lucknow, Uttar Pradesh, India ${ }^{2}$ Department of Urology, CSM Medical University (Upgraded KGMC), Lucknow, Uttar Pradesh, India

\section{Correspondence to} Dr Sagorika Paul, dr_sagarika1612@rediffmail. com.
To cite: Paul S, Dalela D, Prakash J, et al. BMJ Case Reports Published online: [please include Day Month Year] doi:10.1136/bcr-2012008446

\section{DESCRIPTION}

A 21-year-old man had overflow incontinence due to cauda equina syndrome. He applied condom as a urine receptacle without any medical consultation to prevent wetness. The condom was fastened to the penile shaft with two rubber bands (figure 1) and was periodically emptied. He used this system for about 18 months and presented to us with changes in the part of penis that was within the condom sheath resembling 'elephantiasis'. The glans was normal (figure 2B). Skin changes included widespread hypopigmentation and a single ulcer (figure 2A). Suprapubic catheterisation was performed and the patient was advised to apply compressive dressing with glycerine, antibiotic and anti-inflammatory agents. He did not report for follow-up.

Complications due to improper condom catheter usage range from ulceration and necrosis to more severe urethrocutaneous fistulae and urethral diverticulum. ${ }^{1-3}$ Generalised penile oedema is a wellrecognised complication but penile elephantiasis following use of condom as a urinary receptacle has not been described in the literature.
The possible mechanisms may be: (1) lymphovenous stasis secondary to compression by tight rubber band, (2) chronic irritation of skin by urinary accumulation, alkaline $\mathrm{pH}$, infection and moisture or (3) prolonged duration due to impaired sensations. The glans penis was uninvolved probably on account of an alternate lymphovenous drainage through corpus spongiosum. Patients must be warned about this complication, if found using condom as a urinary collection device and be advised safer clean intermittent catheterisation.

\section{Learning points}

Patients with urinary incontinence who are advised prolonged external urinary collection devices like condom catheter should be properly counselled regarding its usage, care and complications.

- Condom and plastic bags should never be used as urine collection devices.

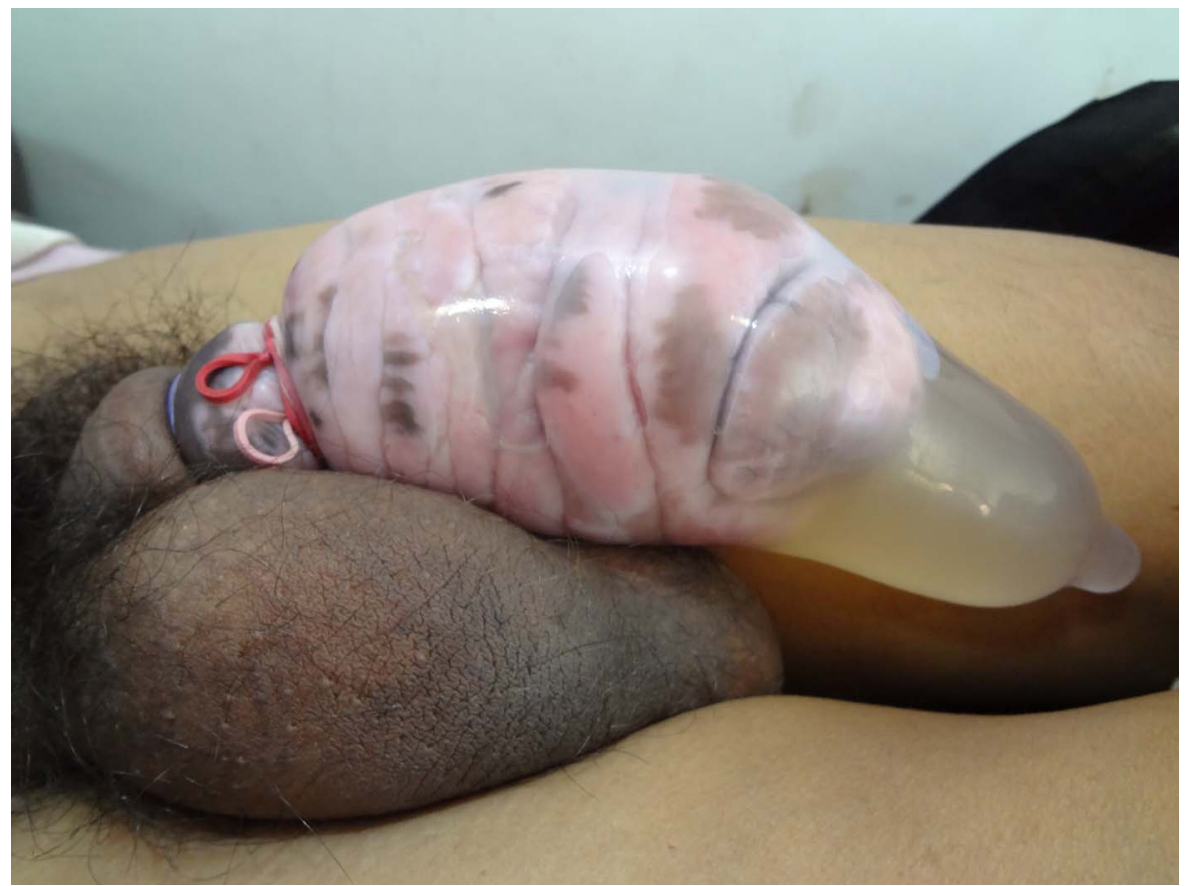

Figure 1 Condom as urinary receptacle with two rubber bands fastened to the penis. 


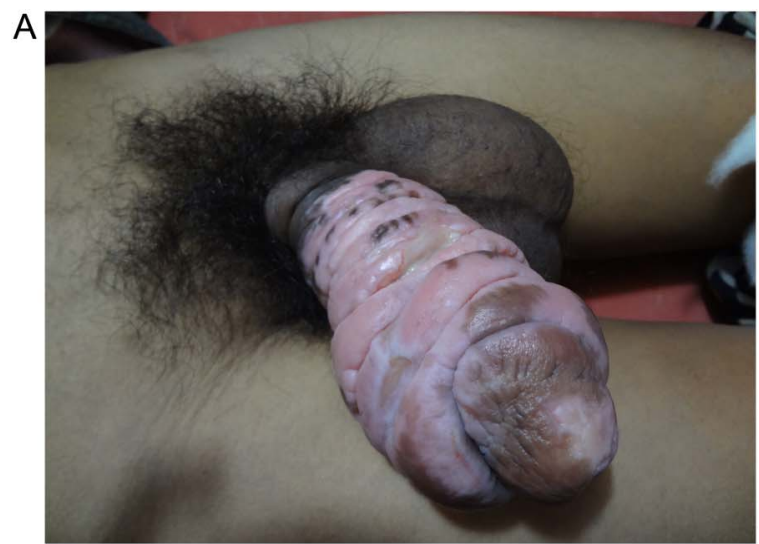

Competing interests None.

\section{Patient consent Obtained.}

Provenance and peer review Not commissioned; externally peer reviewed.

\section{REFERENCES}

1 Golji H. Complications of external condom drainage. Paraplegia 1981;19:189-97.

2 Jayachandran S, Mooppan UM, Kim H. Complications from external (condom) urinary drainage devices. Urology 1985;25:31-4.

3 Melekos MD, Asbach HW. Complications from urinary condom catheters. Urology $1986 ; 27: 88-9$

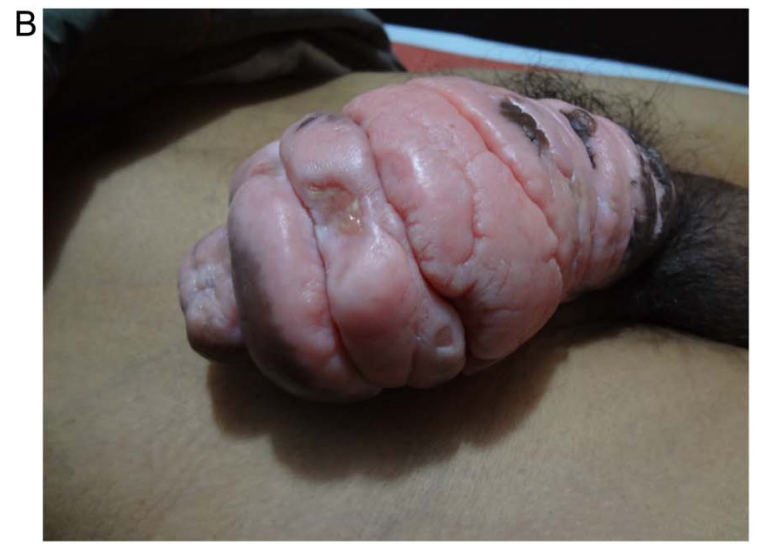

Figure 2 (A) Oedematous shaft of penis with normal glans. (B) Penile skin changes showing widespread hypopigmentation and an ulcer.

Copyright 2013 BMJ Publishing Group. All rights reserved. For permission to reuse any of this content visit http://group.bmj.com/group/rights-licensing/permissions.

BMJ Case Report Fellows may re-use this article for personal use and teaching without any further permission.

Become a Fellow of BMJ Case Reports today and you can:

- Submit as many cases as you like

- Enjoy fast sympathetic peer review and rapid publication of accepted articles

- Access all the published articles

- Re-use any of the published material for personal use and teaching without further permission

For information on Institutional Fellowships contact consortiasales@bmjgroup.com

Visit casereports.bmj.com for more articles like this and to become a Fellow 